\title{
The Utilization of Bauxite Residue with a Calcite-Rich Bauxite Ore in the Pedersen Process for Iron and Alumina Extraction
}

\author{
ADAMANTIA LAZOU, CASPER VAN DER EIJK, KAI TANG, \\ EFTHYMIOS BALOMENOS, LEIV KOLBEINSEN, and JAFAR SAFARIAN
}

\begin{abstract}
Metallurgical grade alumina is produced worldwide through the well-known Bayer process, which unavoidably generates bauxite residue (BR, also known as red mud) in almost equal amounts to alumina. This study aims the valorization of BR through a smelting-reduction process to obtain calcium aluminate slags that can be a proper feed for alumina recovery via the Pedersen process. It investigates the thermodynamics and characteristics of the slags and pig iron produced from mixtures of BR, a bauxite beneficiation byproduct, and lime. In this context, the evolution of the different phases in the slags is studied with advanced analytical techniques and thermodynamic calculations. According to the results, a $\mathrm{CaO} / \mathrm{Al}_{2} \mathrm{O}_{3}$ mass ratio within 1.3 to 1.4 in the slags can yield more $\mathrm{Al}_{2} \mathrm{O}_{3}$-containing leachable phases, such as $\mathrm{CaO} \cdot \mathrm{Al}_{2} \mathrm{O}_{3}$ and $12 \mathrm{CaO} \cdot 7 \mathrm{Al}_{2} \mathrm{O}_{3}$. The cooling dictates the amount and the characteristics of these phases, and the slower cooling rate yields improved slag characteristics. The distribution of the elements between the slag and metal phases shows that iron is separated, and the majority of the $\mathrm{P}, \mathrm{Cr}, \mathrm{Ni}$, and $\mathrm{V}$ are distributed in the produced pig iron, while $\mathrm{S}, \mathrm{Ti}$, and $\mathrm{Si}$ are mostly concentrated in the slags.
\end{abstract}

https://doi.org/10.1007/s11663-021-02086-w

(C) The Author(s) 2021

\section{INTRODUCTION}

Alumina is the feedstock to produce aluminum and is mainly extracted from Bauxite ore ${ }^{[1]}$ Bauxites are composed mostly of alumina hydrate minerals and, in a lesser amount, hydrated aluminum silicate, iron, and titanium minerals. ${ }^{[2]}$ The common industrial way to produce alumina is the well-known Bayer process, ${ }^{[3]}$ in which large amounts of a residue, called bauxite residue (BR), are generated. As an example, 1 ton of alumina production can generate from 0.8 to 1.5 tons of BR (depending largely on the quality of the bauxite ore used). ${ }^{[3]} \mathrm{BR}$ holds all the insoluble/less-soluble compounds of bauxite ore in the Bayer leaching solution, containing $\mathrm{Fe}, \mathrm{Si}$, and $\mathrm{Ti}$ as the main elements, and

ADAMANTIA LAZOU, LEIV KOLBEINSEN, and JAFAR SAFARIAN are with the Department of Materials Science and Engineering, Norwegian University of Science and Technology (NTNU), 7491 Trondheim, Norway. Contact email: Adamantia.lazou@ntnu.no CASPER VAN DER EIJK and KAI TANG are with SINTEF Industry, 7491 Trondheim, Norway. EFTHYMIOS BALOMENOS is with Mytilineos S.A., Metallurgy Business Unit, 32003 Viotia, Greece.

Manuscripe submitted September 2, 2020; accepted January 14, 2021.

Article published online March 8, 2021. some levels of $\mathrm{Ca}$ and $\mathrm{Na}$ ( $\mathrm{Na}$ considers as solution loss) as well as valuable compounds as rare earth elements. ${ }^{[4,5]}$ Extensive research has been done in recent years for the valorization of $\mathrm{BR} \cdot{ }^{[6-12]}$ However, none of those attempts have been industrialized, commonly due to economic obstacles; hence, BR's valorization is still challenging.

A different process for producing alumina was introduced at 1927 by Harald Pedersen, in Norway, and is considered as a method with no significant waste generation. ${ }^{[13,14]}$ This process can be well adapted for the use of any bauxites; in particular, the ones with lower $\mathrm{Al}_{2} \mathrm{O}_{3} / \mathrm{Fe}_{2} \mathrm{O}_{3}$ ratio, which are not proper for the Bayer process. ${ }^{[13,14]}$ The first step is the smelting reduction of bauxite ore with lime $(\mathrm{CaO})$ as a flux and coke as a reducing agent. ${ }^{[15]}$ The produced calcium-aluminate slag should contain phases that are suitable for further alkaline leaching to recover alumina. According to Azof et al., such phases, from higher to lower leachability, are $12 \mathrm{CaO} \cdot 7 \mathrm{Al}_{2} \mathrm{O} 3\left(\mathrm{C}_{12} \mathrm{~A}_{7}\right), \mathrm{CaO} \cdot \mathrm{Al}_{2} \mathrm{O}_{3}$ (CA), and $3 \mathrm{CaO} \cdot \mathrm{Al}_{2} \mathrm{O}_{3}\left(\mathrm{C}_{3} \mathrm{~A}\right) \cdot{ }^{[16]}$ According to Miller and Irgens, the formation of $\mathrm{CaO} \cdot \mathrm{TiO}_{2}(\mathrm{CT})$ from the input $\mathrm{CaO}$ and the $\mathrm{TiO}_{2}$ content of the raw materials will not retard the $\mathrm{Al}_{2} \mathrm{O}_{3}$ recovery. ${ }^{[13]}$ The $\mathrm{SiO}_{2}$ content can be related with the input $\mathrm{CaO}$ to form $2 \mathrm{CaO} \cdot \mathrm{SiO}_{2}$ $\left(\mathrm{C}_{2} \mathrm{~S}\right)$, which has three polymorphs: $\alpha, \beta$, and $\gamma-\mathrm{C}_{2} \mathrm{~S}$. The transformation from $\beta \rightarrow \gamma-\mathrm{C}_{2} \mathrm{~S}$ will make the slag 
self-disintegrate as there is around 12 pct volume expansion. ${ }^{[17]}$ The self-disintegration of the slag will be beneficial in terms of energy consumption for crushing prior to the leaching process. The formation of Al-containing nonleachable phases, particularly Gehlenite $\left(2 \mathrm{CaO} \cdot \mathrm{Al}_{2} \mathrm{O}_{3} \cdot \mathrm{SiO}_{2}, \mathrm{C}_{2} \mathrm{AS}\right)$, should be avoided since they will reduce the alumina recovery. The iron byproduct of the process can be used in the foundry and steel industry if the characteristics, such as the $\mathrm{S}$ content, are appropriate for further use. ${ }^{[14]}$ The solid residue from the leaching step, called grey mud, can be used in cement and fertilizer production if it is classified as an inert material. ${ }^{[13,14,18]}$

Significant experimental and theoretical work has been done about the leachability of the calcium aluminate slags in the framework of the Norwegian Centre SFI-Metal production ${ }^{[19]}$ and ENSUREAL EU project. ${ }^{[2-22]}$ According to laboratory and pilot results, the slags can be used for alumina extraction if their major mineralogical $\mathrm{Al}_{2} \mathrm{O}_{3}$-containing phases are classified as leachable. In the current study, a BR and a calcite-rich bauxite beneficiation byproduct (BBBP) are used as raw materials for the Pedersen process. This study aims to valorize industrial wastes from the mining and alumina industry for iron and alumina recovery. The pyrometallurgical part of the Pedersen process and the optimization of the smelting reduction conditions are experimentally and theoretically studied. The research is supported by thermodynamic calculations and the application of significant material characterization techniques.

\section{MATERIALS AND METHODS}

\section{A. Raw Materials}

BR powder and the calcite-rich BBBP were supplied by Mytilineos Metallurgy Business Unit S.A (former Aluminium of Greece). The BBBP is generated from the Greek (karstic) bauxite ore in order to remove carbonate minerals from the ore entering the Bayer process. Therefore, we emphasize that its availability depends on geographical parameters, and for the one used in this work, a considerable amount is produced every year that can be valorized by the $\mathrm{BR}$ as is studied in this work. The BBBP was received in big lumps and, thus, was crushed and then milled using a ring mill to reduce its particle size. The size reduction of the BBBP to lower than $500 \mu \mathrm{m}$ (sieve size) was done to minimize the inhomogeneities along the ore particles. An additional reason was to achieve a better sintering, contact, and thus a bigger surface area of the raw materials during heating and, therefore, faster smelting and slag formation. In addition, lime was used as a flux with 95.5 pct purity $(\mathrm{CaO}$ wt pct) and was received in powder form. The particle size distribution of the dried powder materials was determined using a laser particle size analyzer, Horiba Partica LA-950. The $D_{90}$ values of BR, BBBP, and lime were $1.25,481$, and $178.5 \mu \mathrm{m}$, respectively. Different mixtures were prepared from dried samples to achieve the desirable ratios between $\mathrm{CaO}$ to $\mathrm{Al}_{2} \mathrm{O}_{3}, \mathrm{SiO}_{2}$, and $\mathrm{TiO}_{2}$, based on mass balance calculations, as shown in Table I.

The chemical analysis of these materials was carried out by X-ray fluorescence (XRF). In Table II, the compositions of the raw materials in dry basis and their LoI are presented. Mineralogical analysis of the raw materials was done by X-ray diffraction (XRD) analysis using a Bruker D8 A25 DAVINCI IM, with $\mathrm{CuK}_{\alpha}$ radiation, in the $2 \theta$ range of 10 to $75 \mathrm{deg}$ diffraction wavelength and $0.02 \mathrm{deg}$ step size.

\section{B. Experimental Setup and Smelting-Reduction Procedure}

The smelting reduction experiments were conducted in a graphite crucible in a $75-\mathrm{kVA}$ open induction furnace. The input mixtures were heated to $1650{ }^{\circ} \mathrm{C} \pm$ $20{ }^{\circ} \mathrm{C}$, and the temperature and power were automatically controlled. The holding time at the target temperature was 90 minutes to ensure complete reduction of iron oxides in addition to proper slag and metal separation. The temperature was recorded with a thermocouple type $\mathrm{C}$ placed in the charged material. After the smelting-reduction trials, the metal settled in the bottom of the crucible due to the significant density difference with the slag, as schematically shown in Figure 1. However, study of the cross-sectioned crucibles after the trials indicated some tiny metal droplets on the side walls of the crucible.

As seen in Table I, the mixtures S-1 and S-2 have the same mixing analogies of $\mathrm{BR}$ and $\mathrm{BBBP}$, but $\mathrm{S}-2$ has higher $\mathrm{CaO} / \mathrm{Al}_{2} \mathrm{O}_{3}$ to study the effect of lime addition. The higher $\mathrm{CaO} / \mathrm{Al}_{2} \mathrm{O}_{3}$ ratio (mixtures $\mathrm{S}-2$ and $\mathrm{S}-3$ ) was designed to form $\mathrm{C}_{2} \mathrm{~S}$ and $\mathrm{CT}$ along with $\mathrm{C}_{12} \mathrm{~A}_{7}$ in the produced slags, based on mass balance calculations and our previous works. ${ }^{[23,24]}$ The mixtures S-3, S-3-S, and $\mathrm{S}-3-\mathrm{R}$ have the same mixing analogies and added lime, while the studied parameter is the effect of the applied cooling rate. The used mass of the $\mathrm{BR}$ and $\mathrm{BBBP}$ was totally $1 \mathrm{~kg}$.

The samples $\mathrm{S}-1$ through $\mathrm{S}-3$ were slowly cooled from $1650{ }^{\circ} \mathrm{C}$ to $1350{ }^{\circ} \mathrm{C} \pm 20{ }^{\circ} \mathrm{C}$ with a rate of $10{ }^{\circ} \mathrm{C} / \mathrm{min}$ based on the programmed temperature profile. After 30 minutes at $1350{ }^{\circ} \mathrm{C}$, the crucible was left in the furnace to be cooled to room temperature. The different cooling rates measured in samples S-3, S-3-S, and S-3-R are shown in Figures 2(a) and (b). For S-3-S, the furnace was shut down after the dwelling time at $1650{ }^{\circ} \mathrm{C}$ and the sample was left to be cooled inside the furnace. For S-3-R, the crucible was taken out from the top open hot furnace (after the dwelling time at $1650{ }^{\circ} \mathrm{C}$ ) and was cooled outside of the furnace in air. The cooling rates that are reported in Table I are based on the average measured cooling rates from the thermocouple readings that were embedded in the sample. In addition, two thermocouples were used in experiment S-3-R in the bottom of the crucible and $5 \mathrm{~cm}$ above (in the molten bath) to examine any temperature gradient. As shown in Figure 2(b), the temperature is slightly higher at the bottom but the temperature difference is considered 
Table I. Mixing Analogies of the Raw Materials and Applied Cooling Rates

\begin{tabular}{|c|c|c|c|c|c|}
\hline Test Name & BR (Wt Pct) & $\mathrm{BBBP}(\mathrm{Wt}$ Pct) & $m \mathrm{CaO} / m \mathrm{Al}_{2} \mathrm{O}_{3} *$ & Added lime (Wt Pct)** & Cooling Path ${ }^{\dagger}$ \\
\hline S-1 & 50 & 50 & 0.96 & - & $10^{\circ} \mathrm{C} / \mathrm{min}$ to $1350^{\circ} \mathrm{C}$ \\
\hline $\mathrm{S}-2$ & 50 & 50 & 1.3 & $12 \mathrm{pct}$ & $10^{\circ} \mathrm{C} / \mathrm{min}$ to $1350{ }^{\circ} \mathrm{C}$ \\
\hline S-3 & 70 & 30 & 1.4 & $19.3 \mathrm{pct}$ & $10^{\circ} \mathrm{C} / \mathrm{min}$ to $1350{ }^{\circ} \mathrm{C}$ \\
\hline S-3-S & 70 & 30 & 1.4 & $19.3 \mathrm{pct}$ & $11.1^{\circ} \mathrm{C} / \min$ to $400^{\circ} \mathrm{C}$ \\
\hline S-3-R & 70 & 30 & 1.4 & $19.3 \mathrm{pct}$ & $52{ }^{\circ} \mathrm{C} / \mathrm{min}$ to $389^{\circ} \mathrm{C}$ \\
\hline
\end{tabular}

* Mass ratio based on mass balance calculations.

**Added mass pet lime $(\mathrm{g})$ per $1 \mathrm{~kg}$ of input mixture.

${ }^{\dagger}$ Averaged cooling rate based on thermocouple readings.

Table II. Chemical Composition of Raw Materials, as Analyzed by XRF and the Lime as Received

\begin{tabular}{lrcc}
\hline $\begin{array}{l}\text { Oxides } \\
\text { Wt Pct }\end{array}$ & BR & BBBP & Lime \\
\hline $\mathrm{Al}_{2} \mathrm{O}_{3}$ & 22.78 & 25.33 & 0.24 \\
$\mathrm{CaO}$ & 8.44 & 34.49 & 95.5 \\
$\mathrm{TiO}_{2}$ & 5.88 & 1.24 & 0.01 \\
$\mathrm{SiO}_{2}$ & 6.35 & 1.11 & 0.46 \\
$\mathrm{Fe}_{2} \mathrm{O}_{3}$ & 43.59 & 5.61 & 0.08 \\
$\mathrm{MgO}$ & 0.56 & - & 0.64 \\
$\mathrm{~V}_{2} \mathrm{O}_{5}$ & 0.30 & - & - \\
$\mathrm{Na}_{2} \mathrm{O}$ & 1.93 & - & 0.12 \\
$\mathrm{MnO}_{\mathrm{Cr}} \mathrm{O}_{3}$ & 0.10 & - & 0.01 \\
$\mathrm{P}_{2} \mathrm{O}_{5}$ & 0.26 & 0.01 & - \\
$\mathrm{NiO}$ & 0.19 & - & 0.02 \\
$\mathrm{~S}$ & 0.07 & - & - \\
$\mathrm{LoI}$ & 0.15 & 0.01 & 0.08 \\
\hline
\end{tabular}

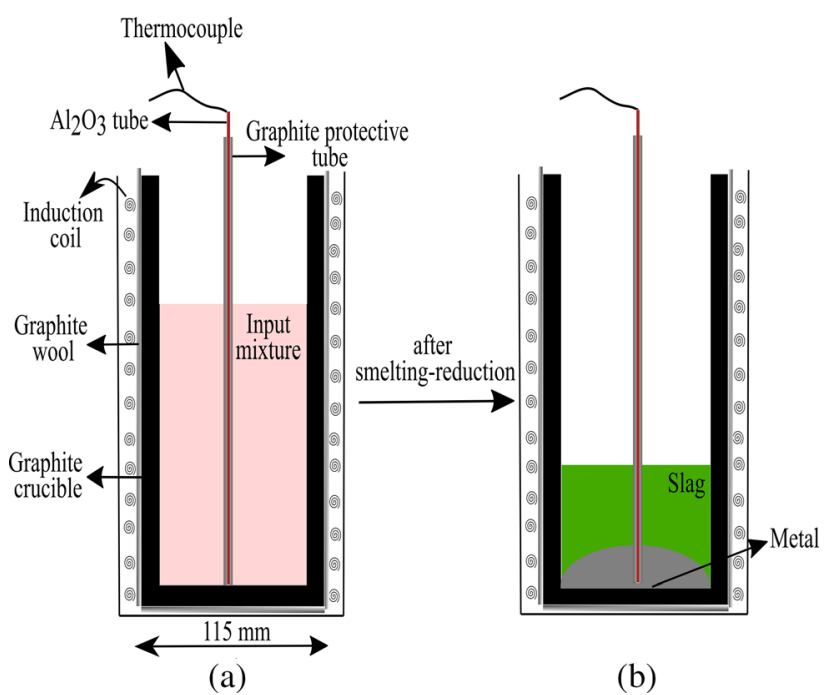

Fig. 1-Schematic of the furnace and input mixture $(a)$ before and (b) after smelting trials.

negligible. This is due to almost uniform induction into the crucible wall and then heat transport into the materials.
After solidification and cooling to room temperature, the crucibles were cut in half to separate the slag and metal. Half of the slag samples were milled to a powder and analyzed by XRF and XRD, while large slag particles from the second half were mounted in epoxy and then ground and polished using SiC emery papers. They were carbon coated for studying the quantitative elemental distribution in the slag phases using a JXA-8500F ${ }^{\text {TM }}$ electron probe microanalyzer (EPMA), supported by wavelength dispersive spectroscopy (WDS). The metal samples were also analyzed with XRF and EPMA techniques.

\section{Theoretical Calculations}

Theoretical calculations were conducted using FactSage 7.3 thermochemical software to support the experimental design and evaluate the obtained results. ${ }^{[25]}$ The compositions of the molten slags and metals were predicted through the equilibrium module based on the raw material compositions and using the commercial FToxid, FSStel, and FactPS databases. Scheil-Gulliver cooling calculations were conducted subsequently on the predicted liquid compositions for the phase distribution in the slags. The main assumptions of the Scheil-Gulliver cooling model have been presented extensively in other articles ${ }^{[25,26]}$ and they are not repeated here. A dedicated EnsureAl database was also used to minimize the lack of data in the commercial databases as it covers the metastable $\mathrm{C}_{12} \mathrm{~A}_{7}$ phase. It is worth noting that the considered thermodynamic properties of the $\mathrm{C}_{12} \mathrm{~A}_{7}$ have been based on the phase equilibrium data that are available in the literature. ${ }^{[27]}$

\section{RESULTS}

\section{A. Characteristics of Raw Materials}

The XRD analysis of the raw materials (Figure 3) shows that iron presents as hematite $\left(\mathrm{Fe}_{2} \mathrm{O}_{3}\right)$ and, in a lower amount, as goethite $(\mathrm{FeOOH})$. Titanium appears as anatase $\left(\mathrm{TiO}_{2}\right)$ and calcium as calcite $\left(\mathrm{CaCO}_{3}\right)$. Aluminum is found in hydroxides as gibbsite $\mathrm{AlO}(\mathrm{OH})_{3}$, diaspore $\alpha-\mathrm{AlO}(\mathrm{OH})$, and boehmite $\beta$ - $\mathrm{AlO}(\mathrm{OH})$, in complex alumino-sodium-silicate phases as $\mathrm{Na}_{1.15} \mathrm{Al}_{1.15}$ $\mathrm{Si}_{0.85} \mathrm{O}_{4}$ and cancrinite $\left(\mathrm{Na}_{6} \mathrm{Ca}_{2}\left(\mathrm{AlSiO}_{4}\right)_{6}\left(\mathrm{CO}_{3}\right)_{2}\right.$ $\left.\left(\mathrm{H}_{2} \mathrm{O}\right)_{2}\right)$, and as katoite $\left(\mathrm{Ca}_{3} \mathrm{Al}_{2}\left(\mathrm{SiO}_{4}\right)(\mathrm{OH})_{8}\right)$ in the BR. 


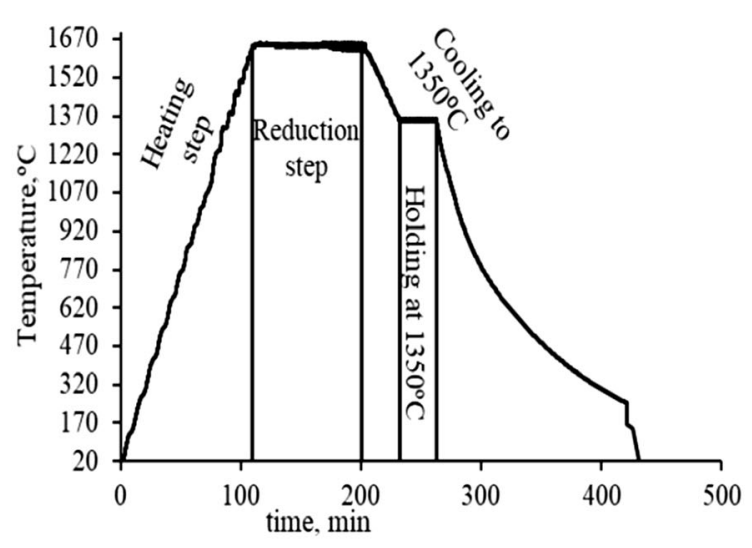

(a)

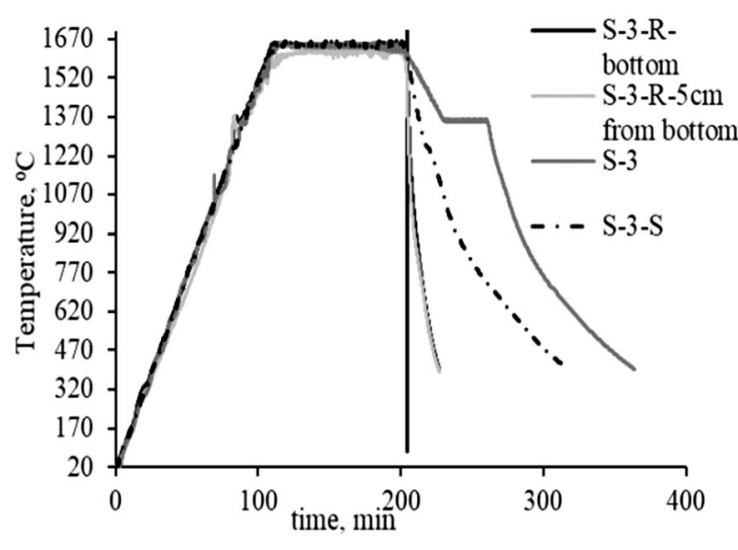

(b)

Fig. 2-Measured temperature profiles of (a) S-1 through S-3 and (b) S-3, S-3-S, and S-3-R with the use of two thermocouples at the crucible bottom (S-3-R-bottom) and $5 \mathrm{~cm}$ above it (S-3-R-5 $\mathrm{cm}$ from the bottom).

Table II shows the XRF analysis of the raw materials used in the present study. BR contains a significant amount of $\mathrm{Fe}_{2} \mathrm{O}_{3}, 43.59$ wt pct, while the alumina content is $22.78 \mathrm{wt}$ pct, indicating levels of alumina losses that occur in the Bayer process.

\section{B. Characteristics of Slags}

\section{Phase identification}

The XRD results of the produced slags are illustrated in Figures 4 and 5. It was observed that there are significant differences compared to the mineralogical compositions of the raw materials (Figure 3) in the smelting reduction. Obviously, there are no $\mathrm{Fe}-$ and $\mathrm{Na}$-containing phases in the produced slags. According to Figure 4, the main phases in slag $\mathrm{S}-1$ are $\mathrm{C}_{2} \mathrm{AS}$ and CA. Weak peaks of $\mathrm{C}_{12} \mathrm{~A}_{7}$ and CT were also detected.

$\mathrm{C}_{12} \mathrm{~A}_{7}$ is the dominant phase for slag $\mathrm{S}-2$, while larnite, $\beta-\mathrm{C}_{2} \mathrm{~S}, \mathrm{CT}, \mathrm{CA}$, and $\mathrm{C}_{2} \mathrm{AS}$ were also detected. Slag S-3 contains $\mathrm{C}_{12} \mathrm{~A}_{7}, \beta-\mathrm{C}_{2} \mathrm{~S}, \mathrm{CT}, \mathrm{CA}$, and weaker peaks of $\mathrm{C}_{2} \mathrm{AS}$ in comparison with slags $\mathrm{S}-1$ and $\mathrm{S}-2$. The carbon detected in all the mentioned slags was due to the contamination from the graphite crucibles and thermowell.

The XRD results of the S-3 with different cooling paths are given in Figure 5. The slag $\mathrm{S}-3-\mathrm{S}$ contains $\mathrm{C}_{12} \mathrm{~A}_{7}, \mathrm{CT}, \mathrm{C}_{3} \mathrm{~A}$ and $\mathrm{C}_{2} \mathrm{AS}$. The slag $\mathrm{S}-3-\mathrm{R}$ contains $\mathrm{C}_{2} \mathrm{AS}, \mathrm{CT}, \mathrm{C}_{3} \mathrm{~A}, \beta-\mathrm{C}_{2} \mathrm{~S}$ and $\mathrm{C}_{12} \mathrm{~A}_{7}$. The peaks of $\mathrm{C}_{2} \mathrm{AS}$ are obviously weaker in the $\mathrm{S}-3-\mathrm{S}$ slag in comparison with the S-3-R, while $\mathrm{C}_{12} \mathrm{~A}_{7}$ has a stronger peak in S-3-S than S-3-R.

The other minor phases, such as $\mathrm{Ca}_{3} \mathrm{Ti}_{2} \mathrm{O}_{7}$, anorthite $\mathrm{CA}_{2} \mathrm{~S}$, and $\mathrm{CaTi}_{2} \mathrm{O}_{4}$, which may form in the slags, could not be identified precisely due to their low intensity peaks in addition to the overlapping of several phases.

\section{Chemical composition}

According to the XRF analysis in Table III, the slags were composed mostly of $\mathrm{CaO}, \mathrm{Al}_{2} \mathrm{O}_{3}, \mathrm{SiO}_{2}$, and $\mathrm{TiO}_{2}$ oxides. Slightly lower $\mathrm{SiO}_{2}$ content than expected was observed for S-3-S (in comparison with S-3 and S-3-R), which may be attributed to some inhomogeneities in the used raw materials or little fluctuation in temperature at elevated temperatures.

The XRF analysis reports the total iron content as $\mathrm{Fe}_{2} \mathrm{O}_{3}$; however, as will be discussed in Section 3, the Fe content of the slags is attributed to metallic entraps, based on the microstructural analysis. To further justify this, magnetic separation of iron by a normal magnet was applied in the S-3-R sample prior to its analysis. As seen in Table III, the $\mathrm{Fe}$ content was significantly reduced. Hence, the $\mathrm{Fe}_{2} \mathrm{O}_{3}$ content of the XRF has been transformed to metallic Fe in Table III.

\section{Microstructural analysis}

As the WDS results are more reliable than those using EDS for the determination of the chemical composition of the phases, we present the WDS results. In Figure 6 and Table IV, the BSE images and WDS analysis of the phases in slags S-1 through S-3 and S-3-R in different locations are presented. We emphasize that we observed even distribution of $\mathrm{SiO}_{2}$ in the main phases (overall distribution), mostly for samples S-2, S-3-S, and S-3-R. However, the compositions of the same phases in different samples were observed to be different regarding the content of the impurities $\left(\mathrm{SiO}_{2}\right.$ and $\left.\mathrm{TiO}_{2}\right)$ in the calcium aluminate phases, as seen in the WDS analysis results in Table IV.

In slag $\mathrm{S}-1$, three phases were observed and marked as $\mathrm{A}, \mathrm{B}$, and $\mathrm{C}$. The continuous phase $\mathrm{A}$ that appears as light gray is attributed to the $\mathrm{C}_{2} \mathrm{AS}$ phase. The dark gray phase $\mathrm{B}$ is rich in $\mathrm{CaO}$ and $\mathrm{Al}_{2} \mathrm{O}_{3}$, and its ratio corresponds to $\mathrm{CA}_{2}$, not $\mathrm{CA}$ as detected with the XRD analysis. The bright-phase $\mathrm{C}$ has a high concentration of $\mathrm{CaO}$ and $\mathrm{TiO}_{2}$, which could be attributed to the CT phase, but it contains 10.8 wt pet $\mathrm{Al}_{2} \mathrm{O}_{3}$. However, a phase like this was not observed in the XRD analysis. According to Dunyushkina et al., Al ions could incorporate in the CT structure even if this phase appears as CT in the XRD spectra. ${ }^{[28]}$ In slag S-2, phase A (dark gray) has an acicular shape and the $\mathrm{C} / \mathrm{A}$ mass ratio is close to the theoretical mass ratio of $\mathrm{C}_{12} \mathrm{~A}_{7}$; however, it contains some $\mathrm{Si}$ and $\mathrm{Ti}$ impurities. It is 


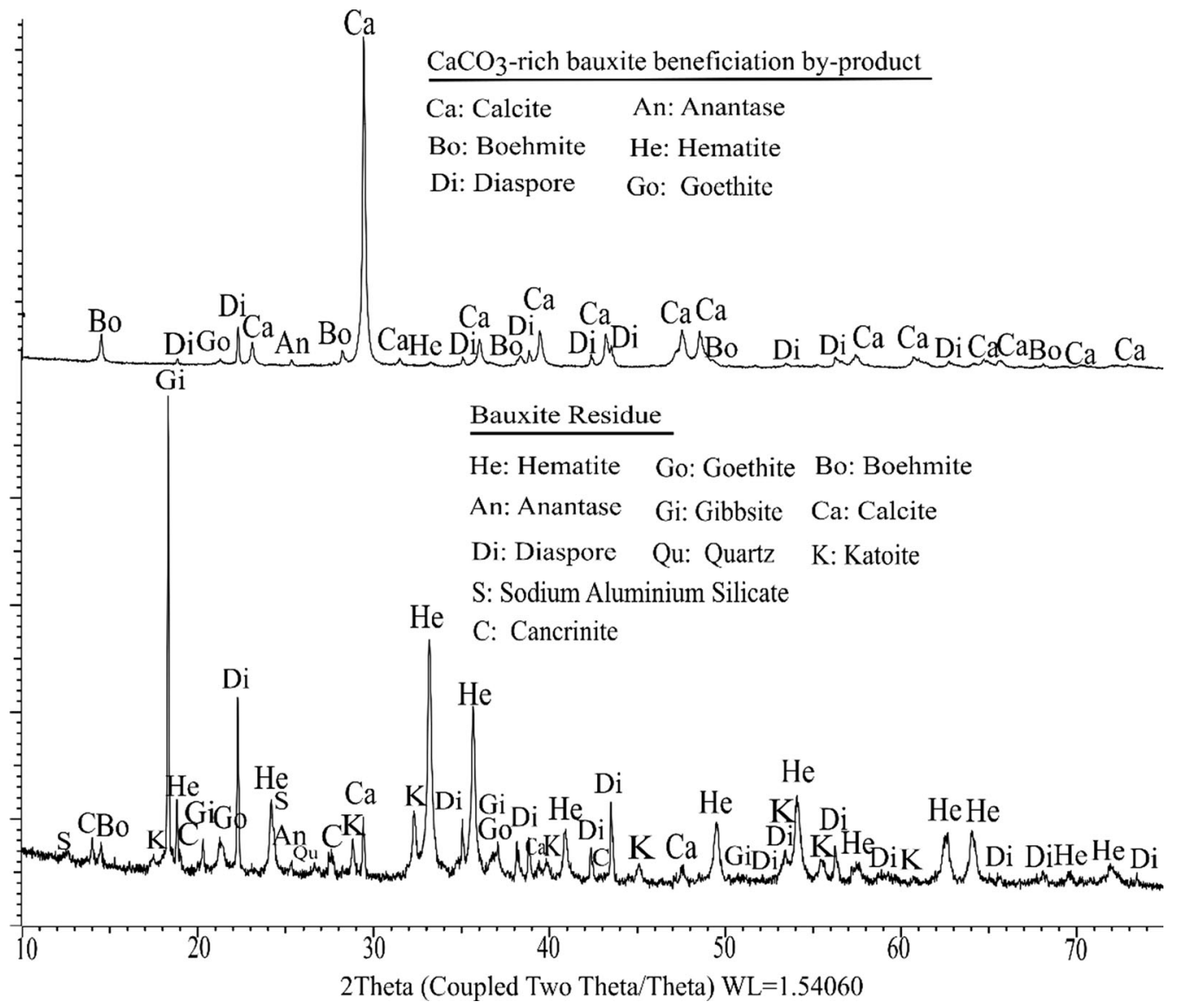

Fig. 3-XRD patterns of the main raw materials used in this study, BR and BBBP.

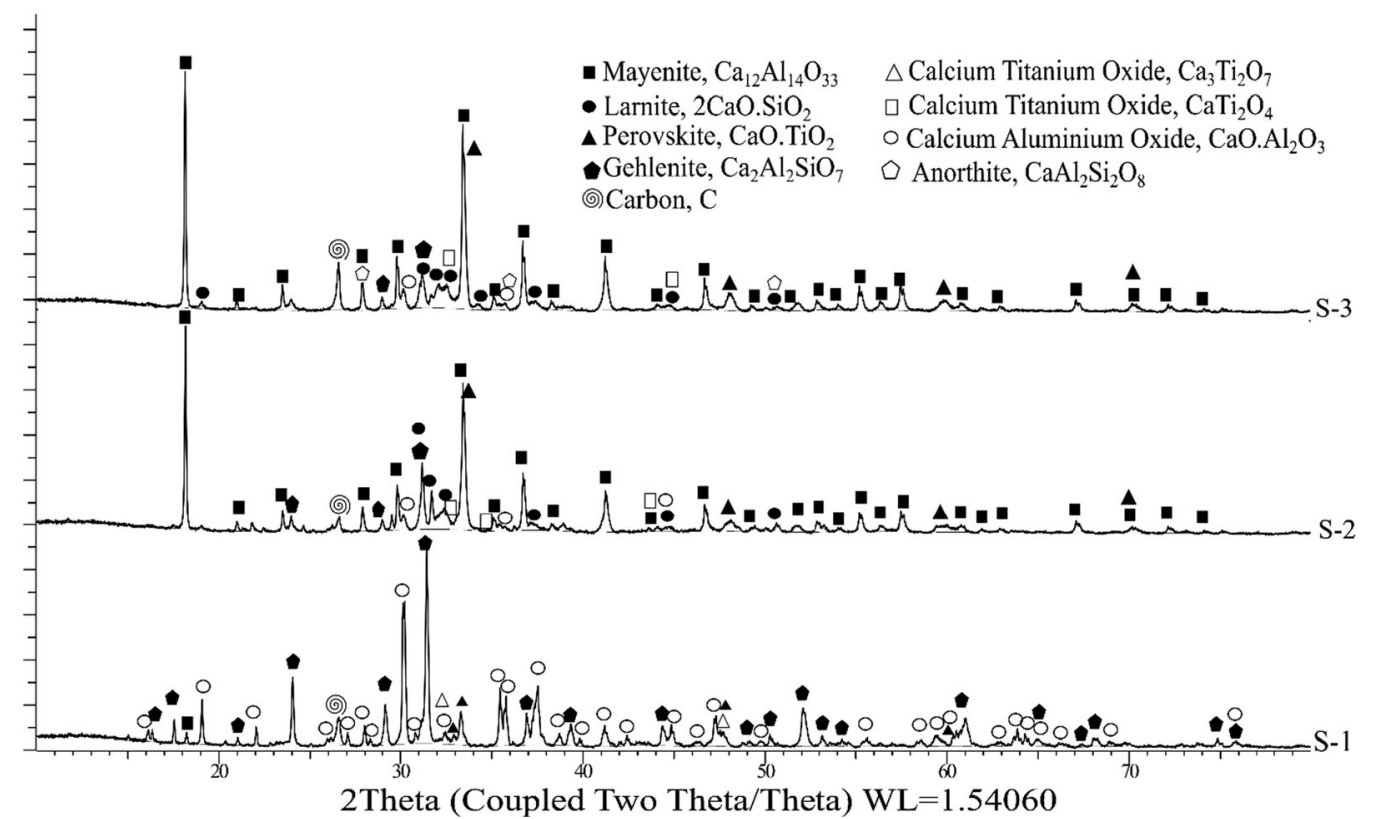

Fig. 4-XRD analysis of slags S-1 through S-3.

worth noting that based on the recent work by Azof, this phase may be $\mathrm{C}_{12} \mathrm{~A}_{7}$ with $\mathrm{Si}$ ions in the locations of some Al ions and is so called "Si-mayenite." ${ }^{[29]}$ The solidified structure $\mathrm{B}$ seems to be a mixture of small $\mathrm{C}_{2} \mathrm{~S}$,
$\mathrm{CT}$, and possible CA phases distributed nonuniformly. The fine structure phase $\mathrm{C}$ may be the $\mathrm{C}_{12} \mathrm{~A}_{7}$ phase containing Si impurities. 


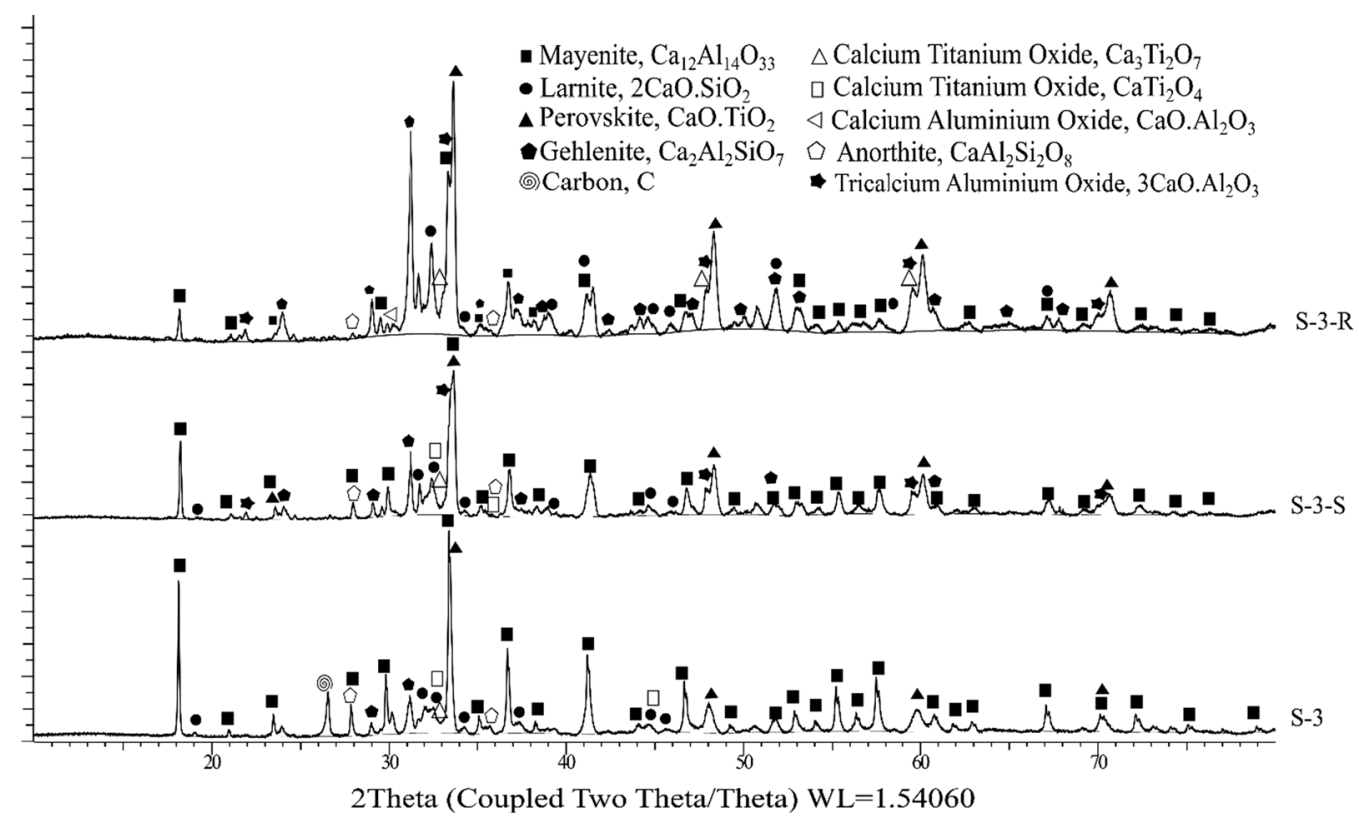

Fig. 5-XRD results of slags S-3, S-3-R, and S-3-S having different cooling paths.

In slag S-3, the bright phase A (Figure 6 and Table IV) was rich in $\mathrm{TiO}_{2}$ and $\mathrm{CaO}$, as in $\mathrm{S}-1$, it was high in $\mathrm{Al}_{2} \mathrm{O}_{3}$; in the XRD analysis, no Ca-Al-Ti-O phase was observed. The light gray phase $\mathrm{B}$ is composed of $\mathrm{CaO}$ and $\mathrm{Al}_{2} \mathrm{O}_{3}$, with the $\mathrm{C} / \mathrm{A}$ mass ratio similar to the $\mathrm{C}_{12} \mathrm{~A}_{7}$. Sulfur has a higher concentration in comparison with the rest of the phases, and based on the literature, the $\mathrm{C}_{12} \mathrm{~A}_{7}$ phase dissolves $\mathrm{S}$ in its structure. ${ }^{[30]}$ Thus, we may claim that this phase is the $\mathrm{C}_{12} \mathrm{~A}_{7}$ phase, as identified in the XRD analysis. The solidified structure $\mathrm{C}$ could be a mixture of $\mathrm{C}_{12} \mathrm{~A}_{7}, \mathrm{C}_{2} \mathrm{~S}$, and $\mathrm{CT}$, which supports the XRD result. The measured analysis of phase $\mathrm{D}$ was difficult to evaluate due to that phase's size and morphology. However, based on WDS and XRD analysis, it could be a mixture of $\mathrm{C}_{2} \mathrm{AS}, \mathrm{C}_{12} \mathrm{~A}_{7}$, and $\mathrm{C}_{2} \mathrm{~S}$ phases, but the identification is not precise in this case. It is observed that metallic iron particles were entrapped in the slag structure, as seen in Figure 6 for slag S-3.

The detected phases in the S-3-S and S-3-R slags were found to be impure, as $\mathrm{SiO}_{2}$ and $\mathrm{TiO}_{2}$ were detected in all the analyzed points. This is possibly due to the increased cooling rate, in comparison with the S-3 slag. In the $\mathrm{S}-3-\mathrm{R}$ sample, it is found that the rapid cooling rate is accompanied with the formation of porosity (Figure 6). Phase A is likely a mixture of $\mathrm{C}_{12} \mathrm{~A}_{7}, \mathrm{CT}$, and $\mathrm{C}_{2} \mathrm{AS}$, but it is evidenced that $\mathrm{Si}$ is evenly dispersed. Phase $\mathrm{B}$ could be the $\mathrm{C}_{2} \mathrm{AS}$ phase detected in the XRD analysis but seems not to be stoichiometrically the same. For clarity, the WDS results of slag S-3-S are not included.

\section{Characteristics of Pig Iron}

\section{Chemical composition}

The chemical analysis of the pig iron samples (Table V) shows that the Fe content of all the metals is $\sim 92 \mathrm{wt}$ pct. The $\mathrm{Si}$ content is low and varies between 0.22 and $0.02 \mathrm{wt}$ pct, while the titanium concentration varies from 1.4 to 0.38 wt pct. $\mathrm{Cu}$ did not appear in the chemical composition of the raw materials (Table II), possibly due to its low concentration, while we see a small amount of it in the metal phase.

\section{Microstructure}

Typical examples of the micrographs of the metallic phase are given in Figure 7. The microstructural analysis of the produced pig irons indicates that they have a relatively similar microstructure, where the graphite flakes are distributed in the matrix, as seen in Figure 7.

At the surface of the metallic phase and mostly close to the graphite flakes, complex carbides were formed that primarily consisted of titanium and vanadium as indicated with the mapping. However, $\mathrm{Si}$ and $\mathrm{Cr}$ elements were found to be evenly distributed in the $\mathrm{Fe}$ matrix. In the metallic phase, M-3-R was observed with less carbides formed in comparison with $\mathrm{M}-3$. This is possibly due to less $\mathrm{Ti}$ in the $\mathrm{M}-3-\mathrm{R}$ (Table $\mathrm{V}$ ) in addition to the applied cooling, as will be discussed subsequently.

\section{Theoretical and Modeling Calculations}

\section{Equilibrium study and distribution of elements}

The predicted equilibrium compositions of metal and slag phases in the molten state are listed in Table VI. The calculations were carried out at the experimental temperature of $1650{ }^{\circ} \mathrm{C}$, and the metal phase was assumed to be carbon saturated. As seen in Table VI, a relatively good agreement was observed between the calculated and experimental (Table III) contents of $\mathrm{Al}_{2} \mathrm{O}_{3}$ and $\mathrm{CaO}$. Besides, a higher but not significant difference was observed for the $\mathrm{SiO}_{2}$ and $\mathrm{TiO}_{2}$. Moreover, FactSage predicts that parts of $\mathrm{TiO}_{2}$ and $\mathrm{Cr}_{2} \mathrm{O}_{3}$ will be reduced to $\mathrm{Ti}_{2} \mathrm{O}_{3}$ and $\mathrm{CrO}$, respectively. 
Table III. Chemical Analysis of Slag Products, as Analyzed by XRF

\begin{tabular}{|c|c|c|c|c|c|c|c|c|c|c|c|}
\hline $\begin{array}{l}\text { Oxides } \\
\text { Wt Pct }\end{array}$ & $\mathrm{Al}_{2} \mathrm{O}_{3}$ & $\mathrm{CaO}$ & $\mathrm{Cr}_{2} \mathrm{O}_{3}$ & $\mathrm{Fe}^{*}$ & $\mathrm{~S}$ & $\mathrm{SiO}_{2}$ & $\mathrm{TiO}_{2}$ & $\mathrm{~V}_{2} \mathrm{O}_{5}$ & $\mathrm{ZrO}_{2}$ & $\mathrm{MgO}$ & $\mathrm{B} * *$ \\
\hline S-1 & 45.01 & 39.20 & 0.08 & 2.76 & 0.26 & 7.60 & 3.21 & 0.05 & 0.14 & 0.54 & 0.75 \\
\hline S-2 & 36.30 & 49.60 & 0.04 & 2.30 & 0.22 & 5.91 & 3.31 & 0.02 & 0.30 & 0.34 & 1.18 \\
\hline S-3 & 35.95 & 47.50 & 0.09 & 2.70 & 0.18 & 7.13 & 4.75 & 0.04 & 0.20 & 0.20 & 1.1 \\
\hline S-3-S & 37.10 & 48.50 & 0.11 & 2.63 & 0.15 & 5.37 & 5.50 & 0.01 & 0.15 & 0.36 & 1.14 \\
\hline S-3-R & 35.60 & 49.70 & 0.03 & 0.29 & 0.24 & 7.60 & 5.80 & 0.03 & 0.24 & 0.36 & 1.15 \\
\hline
\end{tabular}
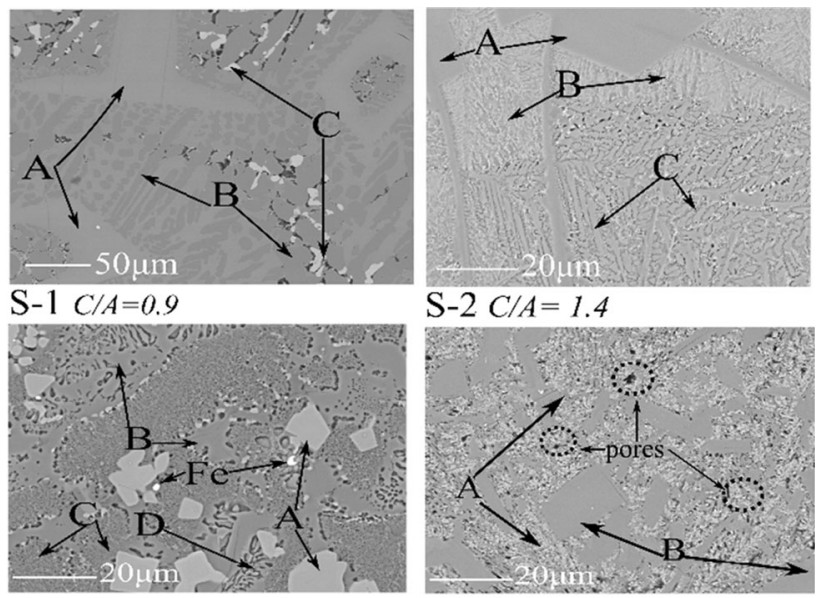

$\mathrm{S}-3 \sim 10^{\circ} \mathrm{C} / \mathrm{min}$

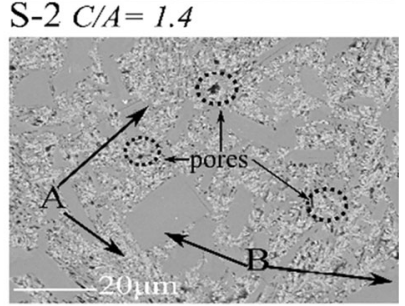

$\mathrm{S}-3-\mathrm{R} \sim 52^{\circ} \mathrm{C} / \mathrm{min}$

Fig. 6-BSE images of slags S-1 through S-3 and S-3-R.

\section{Scheil-Gulliver cooling calculations}

The Scheil-Gulliver cooling calculations are shown in Figure 8. The calculations were done based on the liquid slag compositions previously calculated (Table VI) concentrated in the main components (above 2 pct). The main phases that appear for S-1 in descending order are $\mathrm{CA}, \mathrm{C}_{12} \mathrm{~A}_{7}, \alpha-\mathrm{C}_{2} \mathrm{~S}$, CaTi (ss) that is a $\mathrm{Ca}_{3} \mathrm{Ti}_{2} \mathrm{O}_{7}$ (s) $-\mathrm{Ca}_{3} \mathrm{Ti}_{2} \mathrm{O}_{6}$ (s) solid solution, PERO that is a perovskite $\mathrm{Ca}_{2} \mathrm{Ti}_{2} \mathrm{O}_{6}(\mathrm{~s})-\mathrm{Ca}_{2} \mathrm{Ti}_{2} \mathrm{O}_{5}$ (s) solid solution, and $\gamma-\mathrm{C}_{2} \mathrm{~S}$.

For slag S-2, the predicted phases are $\mathrm{C}_{12} \mathrm{~A}_{7}, \alpha-\mathrm{C}_{2} \mathrm{~S}$, $\mathrm{CaTi}$ (ss), $\mathrm{C}_{3} \mathrm{~A}$, and $\mathrm{Ca}_{3} \mathrm{Ti}_{2} \mathrm{O}_{7}$, and for slag $\mathrm{S}-3$, they are $\mathrm{C}_{12} \mathrm{~A}_{7}, \alpha-\mathrm{C}_{2} \mathrm{~S}, \mathrm{CA}$, CaTi (ss), $\mathrm{C}_{3} \mathrm{~A}$, and $\mathrm{Ca}_{3} \mathrm{Ti}_{2} \mathrm{O}_{7}$.

\section{DISCUSSION}

\section{A. Reduction Reactions and Distribution of Elements}

In the present study, the applied temperature was $1650{ }^{\circ} \mathrm{C}$ to ensure higher reaction rates and proper slag-metal separation. The carbon from the graphite crucible ensures a high carbon activity in the system and presents as $\mathrm{CO}(\mathrm{g})$ gas and dissolved carbon in the liquid iron, $\underline{C}$. In the applied temperature, it is expected that V, $\mathrm{Cr}, \overline{\mathrm{Ni}}$, and $\mathrm{Cu}$ will be reduced to the metallic phase, while sodium oxide is reduced and $\mathrm{Na}$ will evaporate. ${ }^{[31]}$ This has been confirmed through the chemical analysis of the slags and metals (Tables III and V). When solid

carbon reacts with iron oxides, higher temperatures are required to reduce them to metallic iron in comparison with the reduction by $\mathrm{CO}(\mathrm{g})$ since they are less exothermic. The reduction of $\mathrm{Fe}_{2} \mathrm{O}_{3}$ to metallic iron occurs through steps $\mathrm{Fe}_{3} \mathrm{O}_{4} \rightarrow \mathrm{FeO} \rightarrow \mathrm{Fe}$, and most likely the reduction to metallic iron occurs mainly through the $\mathrm{FeO}$ reduction of the slags ${ }^{[16,32]}$ by both solid and dissolved carbon in liquid iron.

Partial Si reduction was observed from the measured compositions of the products (Table $\mathrm{V}$ and Figure 7). The mechanism for the Si transfer in the pig iron phase has been explained in relevant articles ${ }^{[32-34]}$ and is believed to occur through the reaction of $\mathrm{SiO}_{2}$ with $\underline{\mathrm{C}}$. Nevertheless, a small amount of $\mathrm{Si}$ is transferred into the metallic phase, as the $\mathrm{SiO}_{2}$ content of the charge mixtures is low; therefore, low activity of $\mathrm{SiO}_{2}$ in the slag is expected. A higher extent of $\mathrm{SiO}_{2}$ reduction in bauxite smelting has been observed in the case of the smelting reduction of high $\mathrm{SiO}_{2}$-containing bauxites $\left(\mathrm{SiO}_{2}>20 \text { pct }\right)^{[16]}$

The chemical compositions of pig irons (Table V) revealed that some $\mathrm{Ti}$ has been transferred into the metallic phase. It was seen from the micrographs that $\mathrm{Ti}$ was not dissolved in the metallic phase but was precipitated as complex $(\mathrm{Ti}, \mathrm{V})_{x} \mathrm{C}_{y}$ carbides, and based on earlier studies, their precipitation is likely to occur upon cooling and solidification. ${ }^{[15,16]}$ In agreement with Morizane et al., the slower the cooling, the bigger in shape are the carbide precipitates, as seen in Figure $7 .{ }^{[35]}$ Nevertheless, the effect of the anticipated characteristics should be investigated more in terms of the further use of the produced pig irons. The pig iron chemical compositions (Table $\mathrm{V}$ ) revealed low content of $\mathrm{S}$, and this is important for the subsequent processing of the pig iron.

An important aspect in the assessment of the slag/ metal reaction extents is the equilibrium distribution coefficient, $L_{\mathrm{i}}$, of the different species, which is linked to the thermodynamic properties in the metal and slag phases. The distribution coefficient values were calculated based on Eq. [1], and the results (in logarithmic scale) are presented in Figure 9 using the measured compositions by XRF and calculated (FactSage) compositions $^{[36,37]}$ based on the charge materials characteristics.

$$
L_{\mathrm{i}}=\frac{(\text { wt pct i) }}{[\text { wt pct i }]}
$$


where (wt pct $i$ ) is the content of element $i$ in the slag and [wt pct $i$ ] is the content of element $\mathrm{i}$ in the metal. Species with negative $\log _{10} L_{\mathrm{i}}$ are distributed mostly in the metal phase, while the species with positive $\log _{10} L_{\mathrm{i}}$ are concentrated in the slag phase. Based on Figure 9, a similar trend was observed in the distribution behavior of the elements between the experimental results (S-1 through $\mathrm{S}-3$ ), while the $L_{S}$ reveals a proper desulfurization to the slag, as also seen in Table III.

The $L_{\mathrm{i}}$ coefficients determined for the experimental and calculated results show some differences. As mentioned, FactSage predicts that part of the $\mathrm{TiO}_{2}$ and $\mathrm{Cr}_{2} \mathrm{O}_{3}$ will be reduced to $\mathrm{Ti}_{2} \mathrm{O}_{3}$ and $\mathrm{CrO}$, respectively (Table VI), while it overestimates the metallization of $\mathrm{Si}$, $\mathrm{Ti}$, and $\mathrm{Cr}$, as it assumes thermodynamic equilibrium. It is worth noting that the oxidation states of $\mathrm{Ti}^{4+}, \mathrm{Ti}^{3+}$, $\mathrm{Cr}^{3+}$, and $\mathrm{Cr}^{2+}$ have been taken into consideration for the $L_{\mathrm{i}}$ calculation. The oxidation states of $\mathrm{Ti}$ and $\mathrm{Cr}$ are strongly dependent on the oxygen potential that may be changed during solidification and deviate between the experimental conditions and equilibrium calculations. In addition, the distribution of $\mathrm{Si}$ and $\mathrm{Ti}$ (Table VI) will be defined based on both thermodynamic and kinetic parameters, but the model excludes the kinetic effects. In addition, the variations between the model assumptions and the experimental conditions (i.e., lower partial pressure of $\mathrm{O}_{2}$ in the presence of carbon, open furnace conditions, and kinetic effects), and uncertainties about the $\mathrm{Ti}$ content in the applied databases, make the observed differences reasonable. Nevertheless, further experimental and modeling assessment is necessary for further discussion of anticipated discrepancies.

\section{B. Slag Characteristics}

The results obtained for slags $\mathrm{S}-1$ and $\mathrm{S}-2$ clearly indicate that increasing the lime addition enhances the formation of the preferablephases, as also seen from the theoretical calculations in Figure 8. The formation of $\mathrm{CT}$ and $\mathrm{C}_{2} \mathrm{~S}$ should be taken into consideration in terms of the slag chemistry and proper $\mathrm{CaO}$ additions. Slag S-3 was found to contain similar phases as slag S-2, and their $\mathrm{C} / \mathrm{A}$ mass ratios are quite similar.
For slags S-3, S-3-R, and S-3-S, it was observed that the slower cooling rate, that is, $\sim 10{ }^{\circ} \mathrm{C} / \mathrm{min}$ (Table I), yields more $\mathrm{C}_{12} \mathrm{~A}_{7}$ in the slag as the $\mathrm{C}_{12} \mathrm{~A}_{7}$ phase is not dominant when the cooling rate becomes higher $(\sim 52$ ${ }^{\circ} \mathrm{C} / \mathrm{min}$, Table I). Besides, the increased cooling rate is accompanied with the formation of less pure leachable phases with higher Si and Ti impurities, as illustrated by the WDS analysis in Table IV. The effect that this may have on the recovery of alumina can be the dissolution of $\mathrm{Si}$ in the leaching step that affects both further desilication of the sodium aluminate solution, which causes some $\mathrm{Al}$ loss, and the purity of the alumina product. ${ }^{[38]}$ It is worth noting that based on the EPMA results (Figure 6) in all slags, the CT phase seems to incorporate $\mathrm{Al}$ in its structure, as observed in Reference 28 , while in another study regarding the $\mathrm{CaO}-\mathrm{Al}_{2} \mathrm{O}_{3}$ $\mathrm{TiO}_{2}$ system, the formation of $\mathrm{Ca}_{3} \mathrm{Ti}_{8} \mathrm{Al}_{12} \mathrm{O}_{37}$ is evidenced. ${ }^{[39]}$ However, the formation of complex Ca-Ti-Al-O phase should be investigated more in addition to the effects it may have in $\mathrm{Al}_{2} \mathrm{O}_{3}$ leaching. Nevertheless, this case most likely occurs for high $\mathrm{Ti}$ concentrations in the raw materials and the obtained slag and is beyond the scope of the present study as we did not detect $\mathrm{Ca}_{3} \mathrm{Ti}_{8} \mathrm{Al}_{12} \mathrm{O}_{33}$ by the EPMA and XRD analysis.

\section{Stabilization of $\mathrm{C}_{12} \mathrm{~A}_{7}$}

Both the experimental results and the theoretical calculations indicate that $\mathrm{C}_{12} \mathrm{~A}_{7}$ is a stable phase at low temperatures. According to the literature, in both inert and dry atmosphere conditions, $\mathrm{C}_{12} \mathrm{~A}_{7}$ will not form since it needs excess $\mathrm{O}_{2}$ to be stabilized; thus, an $\mathrm{O}_{2}$ containing atmosphere or small amount of moisture in an inert atmosphere can enhance the formation of $\mathrm{C}_{12} \mathrm{~A}_{7} \cdot{ }^{[40-42]}$ The experiments in the current study were conducted in top open crucibles and in exposure to air with normal humidity; hence, the $\mathrm{C}_{12} \mathrm{~A}_{7}$ phase is expected to appear in the slag samples. Nityanand and Fine studied the effect of $\mathrm{TiO}_{2}$ on the liquidus temperatures of $\mathrm{CaO}-\mathrm{Al}_{2} \mathrm{O}_{3}$ as a function of the oxygen potential and concluded that $\mathrm{TiO}_{2}$ can have a similar effect as the water vapor in the $\mathrm{C}_{12} \mathrm{~A}_{7}$ formation. ${ }^{[43]}$ Azof has recently shown that the existence of a small amount

Table IV. WDS Analysis of Slags S-1, S-2, S-3, and S-3-R

\begin{tabular}{|c|c|c|c|c|c|c|c|c|c|c|}
\hline & \multirow[b]{2}{*}{ Appearance in BSE } & \multirow[b]{2}{*}{ Phase/Area } & \multirow[b]{2}{*}{ Suggested Compound } & \multicolumn{7}{|c|}{ Oxide (Wt Pct) } \\
\hline & & & & $\mathrm{CaO}$ & $\mathrm{Al}_{2} \mathrm{O}_{3}$ & $\mathrm{SiO}_{2}$ & $\mathrm{TiO}_{2}$ & $\mathrm{FeO}$ & $\mathrm{S}$ & $\mathrm{MgO}$ \\
\hline \multirow[t]{3}{*}{ S-1 } & light gray & A & $\mathrm{C}_{2} \mathrm{AS}$ & 38.22 & 40.56 & 20.16 & 0.86 & 0.03 & 0.04 & 0.13 \\
\hline & dark gray & $\mathrm{B}$ & $\mathrm{CA}$ & 33.03 & 66.51 & 0.33 & 0.05 & 0 & 0.04 & 0.05 \\
\hline & white & $\mathrm{C}$ & $\mathrm{CT}$ & 42.89 & 10.81 & 1.91 & 44.24 & 0.02 & 0.01 & 0.11 \\
\hline \multirow[t]{3}{*}{$\mathrm{S} 2$} & dark gray & A & $\mathrm{C}_{12} \mathrm{~A}_{7}$ (Si impurities) & 44.92 & 46.86 & 5.66 & 1.74 & 0 & 0.01 & 0.16 \\
\hline & light gray & $\mathrm{B}$ & $\mathrm{C}_{2} \mathrm{~S} / \mathrm{CT} / \mathrm{CA}$ & 52.61 & 37.86 & 5.46 & 3.85 & 0.01 & 0.63 & 0.35 \\
\hline & gray & $\mathrm{C}$ & $\mathrm{C}_{12} \mathrm{~A}_{7}$ (Si-impurities) & 50.27 & 41.06 & 4.19 & 3.45 & 0.01 & 0.58 & 0.5 \\
\hline \multirow[t]{4}{*}{ S-3 } & bright & A & $\mathrm{CT}$ & 45.89 & 13.81 & 1.33 & 37.45 & 0.01 & 0.01 & 0.07 \\
\hline & light gray & $\mathrm{B}$ & $\mathrm{C}_{12} \mathrm{~A}_{7}$ & 49.51 & 48.17 & 0 & 0.5 & 0.01 & 2.13 & 0.09 \\
\hline & eutectic & $\mathrm{C}$ & $\mathrm{C}_{12} \mathrm{~A}_{7} / \mathrm{C}_{2} \mathrm{~S} / \mathrm{CT}$ & 54.69 & 33.66 & 5.52 & 4.11 & 0.01 & 0.03 & 0.26 \\
\hline & gray dendritic & $\mathrm{D}$ & $\mathrm{C}_{12} \mathrm{~A}_{7} / \mathrm{C}_{2} \mathrm{AS} / \mathrm{C}_{2} \mathrm{~S}$ & 51.39 & 36.83 & 7.06 & 1.99 & 0.02 & 1.35 & 0.22 \\
\hline \multirow[t]{2}{*}{ S-3-R } & fine Structured & A & $\mathrm{C}_{12} \mathrm{~A}_{7} / \mathrm{CT} / \mathrm{C}_{2} \mathrm{AS}$ & 44.64 & 38.11 & 6.98 & 9.58 & 0.22 & 0.46 & 0.22 \\
\hline & light gray & $\mathrm{B}$ & $\mathrm{C}_{2} \mathrm{AS}$ & 39.97 & 48.04 & 9.66 & 2.13 & 0.22 & 0.16 & 0.02 \\
\hline
\end{tabular}


Table V. Chemical Analysis of Metal Products, as Analyzed by XRF and LECO

\begin{tabular}{|c|c|c|c|c|c|c|c|c|c|c|c|}
\hline $\begin{array}{l}\text { Pig Iron } \\
\text { Wt Pct }\end{array}$ & $\mathrm{Fe}$ & $\mathrm{Si}$ & $\mathrm{Ti}$ & $\mathrm{C}^{*}$ & $\mathrm{~S}$ & $\mathrm{P}$ & $\mathrm{Mn}$ & $\mathrm{Ni}$ & V & $\mathrm{Cr}$ & $\mathrm{Cu}$ \\
\hline M-1 & 92.74 & 0.22 & 0.75 & 5.22 & $<0.001$ & 0.08 & 0.04 & 0.32 & 0.15 & 0.30 & 0.03 \\
\hline M-2 & 91.48 & 0.15 & 1.40 & 5.54 & $<0.002$ & 0.09 & 0.05 & 0.52 & 0.17 & 0.27 & 0.04 \\
\hline M-3 & 92.31 & 0.10 & 1.01 & 5.23 & $<0.001$ & 0.09 & 0.06 & 0.52 & 0.14 & 0.28 & 0.03 \\
\hline M-3-S & 92.09 & 0.02 & 0.38 & 5.85 & $<0.001$ & 0.13 & 0.04 & 0.62 & 0.20 & 0.34 & 0.04 \\
\hline M-3-R & 92.28 & 0.03 & 0.52 & 5.82 & $<0.001$ & 0.10 & 0.06 & 0.42 & 0.20 & 0.33 & 0.03 \\
\hline
\end{tabular}
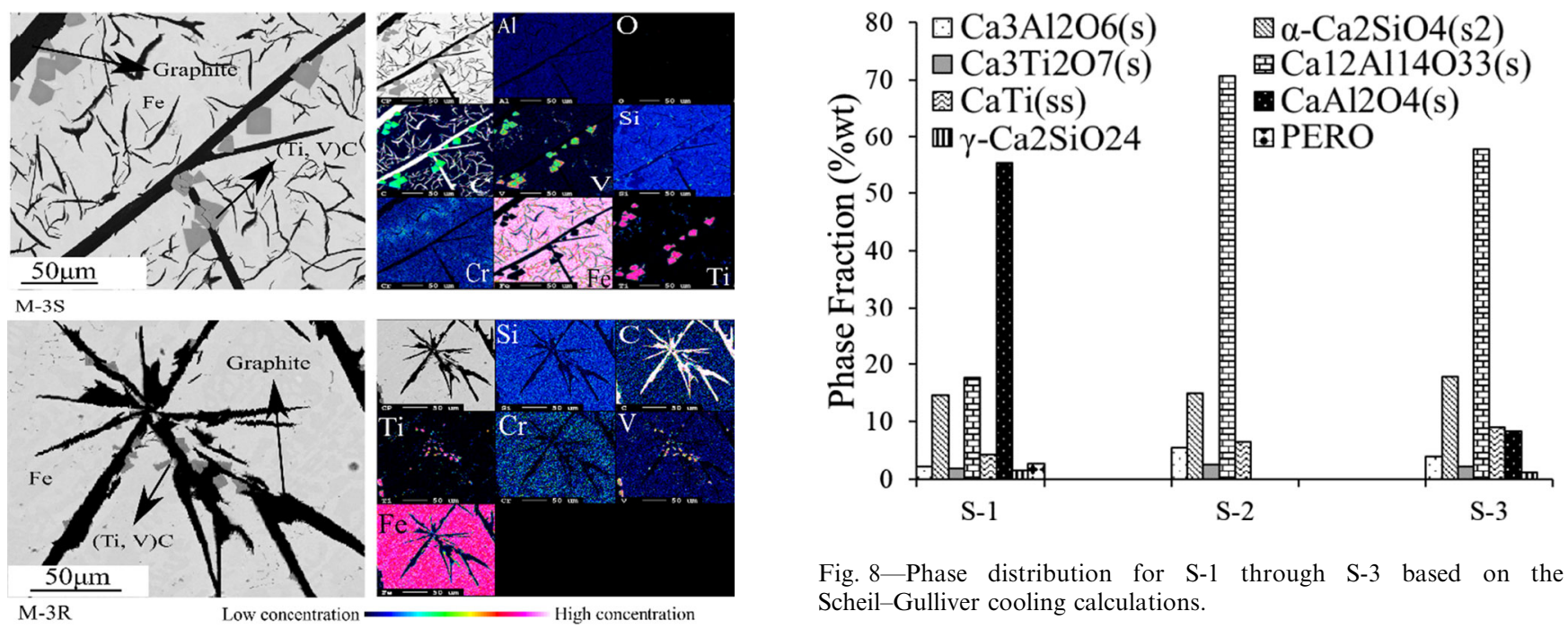

Fig. 8-Phase distribution for S-1 through S-3 based on the Scheil-Gulliver cooling calculations.

Fig. 7-BSE images and elemental X-ray mapping of typical produced metal (M-3 and M-3-R).

Table VI. Equilibrium Composition of the Slags S-1, S-2, and S-3 and Metals M-1, M-2, and M-3 at $1650{ }^{\circ} \mathrm{C}$ as Calculated by FactSage

\begin{tabular}{lccccccccccc}
\hline & \multicolumn{1}{c}{ Slag Phases (Wt Pct) } \\
\cline { 2 - 11 } & $\mathrm{Al}_{2} \mathrm{O}_{3}$ & $\mathrm{CaO}$ & $\mathrm{Cr}_{2} \mathrm{O}_{3}$ & $\mathrm{CrO}$ & $\mathrm{Fe}_{2} \mathrm{O}_{3}$ & $\mathrm{~S}$ & $\mathrm{SiO}_{2}$ & $\mathrm{TiO}_{2}$ & $\mathrm{Ti}_{2} \mathrm{O}_{3}$ & $\mathrm{Na}_{2} \mathrm{O}$ & $\mathrm{MgO}$ \\
\hline $\mathrm{S}-1$ & 45.23 & 43.81 & $1.09 \times 10^{-5}$ & $2.28 \times 10^{-4}$ & $1.08 \times 10^{-5}$ & 0.11 & 5.57 & 2.84 & 1.50 & 0.10 & 0.44 \\
$\mathrm{~S}-2$ & 38.10 & 51.52 & $1.42 \times 10^{-5}$ & $1.7 \times 10^{-4}$ & $1.80 \times 10^{-5}$ & 0.10 & 5.20 & 3.27 & 1.04 & 0.08 & 0.46 \\
$\mathrm{~S}-3$ & 36.19 & 50.89 & $1.36 \times 10^{-5}$ & $1.81 \times 10^{-4}$ & $1.45 \times 10^{-5}$ & 0.12 & 6.50 & 3.82 & 1.42 & 0.10 & 0.66 \\
\hline
\end{tabular}

Metal Phases (Wt Pct)

\begin{tabular}{|c|c|c|c|c|c|c|c|c|c|c|}
\hline & $\mathrm{Fe}$ & $\mathrm{Si}$ & $\mathrm{Ti}$ & $\mathrm{S}$ & $\mathrm{C}$ & $\mathrm{P}$ & V & $\mathrm{Cr}$ & $\mathrm{Al}$ & $\mathrm{Ni}$ \\
\hline M-1 & 88.96 & 1.25 & 2.6 & $1.04 \times 10^{-3}$ & 5.6 & 0.22 & 0.4 & 0.46 & 0.11 & 0.14 \\
\hline M-2 & 91.08 & 0.46 & 1.21 & $4.49 \times 10^{-4}$ & 5.66 & 0.22 & 0.41 & 0.47 & 0.11 & 0.15 \\
\hline M-3 & 90.41 & 0.65 & 1.62 & $6.29 \times 10^{-4}$ & 5.68 & 0.23 & 0.46 & 0.49 & 0.11 & 0.14 \\
\hline
\end{tabular}

of $\mathrm{SiO}_{2}$ in the $\mathrm{CaO}-\mathrm{Al}_{2} \mathrm{O}_{3}$ slags has a similar effect, and they called a $\mathrm{C}_{12} \mathrm{~A}_{7}$ phase that contains $\mathrm{Si}$ " $\mathrm{Si}$-mayenite." ${ }^{[29]}$ Kim et al. observed the dissolution of sulfur in the $\mathrm{C}_{12} \mathrm{~A}_{7}$ structure, as we also observed in the current study. ${ }^{[30]}$ Based on the EPMA analysis of S-3 (Figure 6 and Table IV), we can see that the $\mathrm{C}_{12} \mathrm{~A}_{7}$ phase has $\mathrm{S}$ in its structure. The free oxygen in the structure of $\mathrm{C}_{12} \mathrm{~A}_{7}$ can be substituted by other anions, such as $\mathrm{S}, \mathrm{F}^{-}, \mathrm{Cl}^{-}$, and
$\left.\mathrm{OH}^{-},{ }^{[30,44}{ }^{46}\right]$ which can be characterized as stabilizing agents. Hence, we may claim that under the applied conditions, all the critical parameters for $\mathrm{C}_{12} \mathrm{~A}_{7}$ stabilization (the excess $\mathrm{O}_{2}$, existence of moisture, $\mathrm{TiO}_{2}$, and S) have enhanced its formation. Nevertheless, regarding the complexity of the system, we cannot conclude which of the aforementioned parameters plays the most important role in $\mathrm{C}_{12} \mathrm{~A}_{7}$ stabilization. 


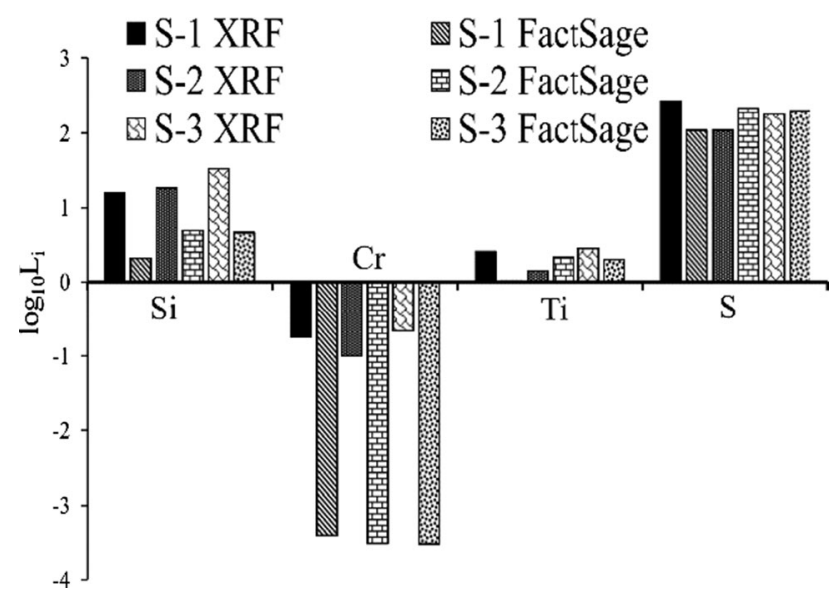

Fig. 9-Measured and calculated at the $1650{ }^{\circ} \mathrm{C}$ distribution coefficient $L_{i}$ in the logarithmic scale for $\mathrm{Si}, \mathrm{Ti}, \mathrm{S}$, and $\mathrm{Cr}$.

\section{Effect of slag chemistry and cooling rate on $\mathrm{C}_{12} \mathrm{~A}_{7}$} formation

Based on the anticipated experimental and theoretical results, we may claim that $\mathrm{Ca}$ diffusion plays an important role in the formation of several $\mathrm{C}_{x} \mathrm{~A}_{y}$ phases, in agreement with the literature. ${ }^{[47,48]}$ According to the microstructure analysis in Figure 6 and Table IV, it seems that in slow cooling (slag S-3), the mayenite phase appears as a pure phase. Thus, in connection to the slag chemistry, it is possible for $\mathrm{C}_{12} \mathrm{~A}_{7}$ to precipitate directly from the melt. On the other hand, based on the literature, it is possible that $\mathrm{C}_{3} \mathrm{~A}$ reacts with $\mathrm{Al}_{2} \mathrm{O}_{3}$ to form $\mathrm{C}_{12} \mathrm{~A}_{7}$ as $\mathrm{C}_{3} \mathrm{~A}$ is less reactive and stable. ${ }^{[16,49]}$ When we employed high cooling rates, $\mathrm{C}_{2} \mathrm{AS}$ and $\mathrm{C}_{3} \mathrm{~A}$ were favored instead of $\mathrm{C}_{12} \mathrm{~A}_{7}$. Based on the EPMA results, the impurities in the mayenite phase were increased ( $\mathrm{Si}$ and $\mathrm{Ti}$ impurities in $\mathrm{C}_{12} \mathrm{~A}_{7}$, slag $\mathrm{S}-3-\mathrm{S}$, and slag S-3-R) while increasing the cooling rate and the appearance of $\mathrm{C}_{2} \mathrm{AS}$ was evidenced. Consequently, we may claim that when the cooling rate becomes high, there is not enough time for complete diffusion of the species (in particular, $\mathrm{Ca}$ ions). Thus, it is possible that the remaining $\mathrm{CA}$ or $\mathrm{Al}_{2} \mathrm{O}_{3}$ will react with the coexisting $\mathrm{C}_{2} \mathrm{~S}$ to form $\mathrm{C}_{2} \mathrm{AS}$. This can be confirmed further from the XRD of slag S-3-S (Figure 5), where the $\mathrm{C}_{12} \mathrm{~A}_{7}$, $\mathrm{C}_{2} \mathrm{AS}, \mathrm{C}_{2} \mathrm{~S}$, and $\mathrm{C}_{3} \mathrm{~A}$ coexist. The $\mathrm{C}_{2} \mathrm{AS}$ formation agrees with literature sources, ${ }^{[17]}$ where during rapid cooling there is not enough time for diffusion depending on transformations and causing the $\mathrm{C}_{2} \mathrm{AS}$. Hence, the $\mathrm{C}_{12} \mathrm{~A}_{7}$ is formed only in a low concentration since its formation will not be kinetically favored, and $\mathrm{C}_{2} \mathrm{AS}$, along with $\mathrm{C}_{3} \mathrm{~A}$, will be the dominant phase. The suggested mechanism here is schematically shown in Figure 10.

It is worth noting that the thermodynamic calculations did not predict the formation of $\mathrm{C}_{2} \mathrm{AS}$ since the present model excludes the kinetic effects, and we may point out that the formation of the different phases is highly dependent on the cooling rate. Our previous experimental work showed that the $\mathrm{CaO} / \mathrm{Al}_{2} \mathrm{O}_{3}$ ratio

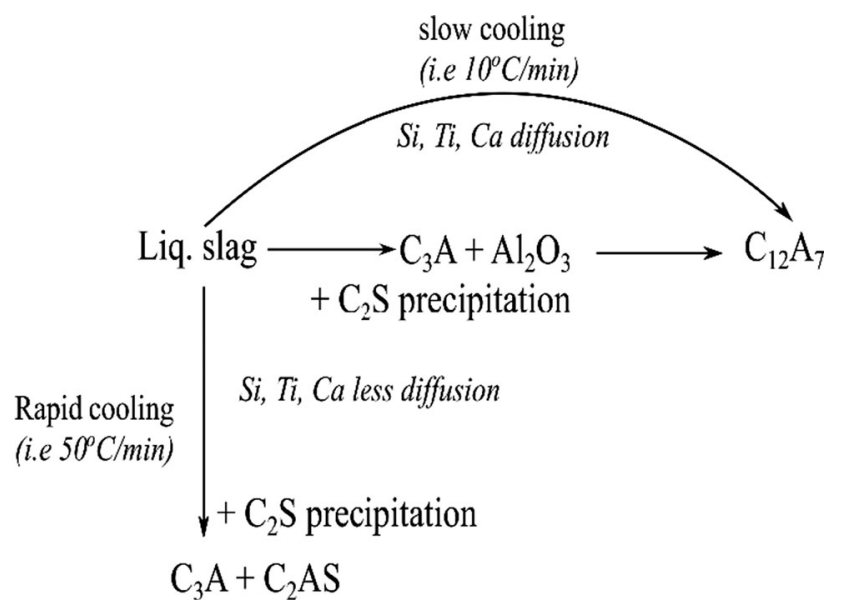

Fig. 10 - Suggested mechanism for the formation of $\mathrm{C}_{12} \mathrm{~A}_{7}$ and $\mathrm{C}_{2} \mathrm{AS}$ phases dependent on the cooling rate.

must be in a range of 0.95 to 1.5 in the final slag. ${ }^{[23,24]}$ Therefore, the operational parameters should be controlled regarding the target $\mathrm{CaO} / \mathrm{Al}_{2} \mathrm{O}_{3}$ ratio and the cooling conditions. Based on the present study, applying slow cooling conditions and targeting a $\mathrm{CaO} / \mathrm{Al}_{2} \mathrm{O}_{3}$ mass ratio of approximately 1.3 can provide a slag with proper characteristics for the subsequent alumina recovery. We intend to produce slags with higher amounts of $\mathrm{Al}_{2} \mathrm{O}_{3}$-containing leachable phases with the highest purities to attain the highest possible alumina recovery. The alumina recovery depends on both slag characteristics and later hydrometallurgical treatment. If $\mathrm{Al}$ is completely in the leachable phases, the $\mathrm{Al}$ recovery in the integrated process will be more than 90 pct. ${ }^{[50]}$

\section{CONCLUSIONS}

The carbothermic smelting reduction of a BR and a calcium-carbonate rich BBBP was done in order to separate the iron as pig iron and produce calcium-aluminate slags for further alumina recovery. The main conclusions drawn from the study are as follows.

1. The iron oxide reduction and separation from the slags was properly done, yielding pig iron containing low concentrations of $\mathrm{Si}, \mathrm{S}, \mathrm{P}, \mathrm{Ti}, \mathrm{V}$, and $\mathrm{Cr}$. In the metal, Ti and $\mathrm{V}$ appear as complex carbide precipitates.

2. It was found that the sodium oxide of the BR is completely reduced and removed from the system at elevated temperatures, yielding a Na-free slag.

3 . Both the experimental work and FactSage equilibrium calculations showed that the produced slags are richer in $\mathrm{Si}, \mathrm{Ti}$, and $\mathrm{S}$ than the metal, while the pig iron is richer in Cr. FactSage predicts much higher $\mathrm{Si}$ and $\mathrm{Cr}$ concentrations in the metal phase than do the experiments.

4. The increase of the $\mathrm{CaO} / \mathrm{Al}_{2} \mathrm{O}_{3}$ ratio enhanced the formation of the desirable leachable $\mathrm{C}_{12} \mathrm{~A}_{7}$ and $\mathrm{CA}$ phases. 
5. It was observed that the cooling rate significantly affects the characteristics of the slags and the leachable $\mathrm{C}_{12} \mathrm{~A}_{7}$ phase is obtained mainly under slower cooling rates.

6. A possible mechanism for the formation of the $\mathrm{C}_{12} \mathrm{~A}_{7}$ was suggested, in which the $\mathrm{C}_{12} \mathrm{~A}_{7}$ is formed directly from the melt due to the $\mathrm{C}_{3} \mathrm{~A}$ and $\mathrm{Al}_{2} \mathrm{O}_{3}$ reaction at slow cooling rates, while a high cooling rate interrupts the diffusion of the species, in particular $\mathrm{Ca}$, and $\mathrm{C}_{2} \mathrm{AS}$ with $\mathrm{C}_{3} \mathrm{~A}$ is formed instead.

\section{ACKNOWLEDGMENTS}

This research was performed within the ENSUREAL project and received funding from the EU Horizon 2020 Program (H2020/2014-2020) under Grant Agreement No. 767533, which is gratefully acknowledged.

\section{FUNDING}

Open access funding provided by NTNU Norwegian University of Science and Technology (incl St. Olavs Hospital - Trondheim University Hospital).

\section{OPEN ACCESS}

This article is licensed under a Creative Commons Attribution 4.0 International License, which permits use, sharing, adaptation, distribution and reproduction in any medium or format, as long as you give appropriate credit to the original author(s) and the source, provide a link to the Creative Commons licence, and indicate if changes were made. The images or other third party material in this article are included in the article's Creative Commons licence, unless indicated otherwise in a credit line to the material. If material is not included in the article's Creative Commons licence and your intended use is not permitted by statutory regulation or exceeds the permitted use, you will need to obtain permission directly from the copyright holder. To view a copy of this licence, visit http://creativec ommons.org/licenses/by/4.0/.

\section{REFERENCES}

1. R. Lumley: Fundamentals of Aluminium Metallurgy: Production, Processing and Applications, 1st ed., Woodhead Publishing Limited, Cambridge, United Kingdom, 2011, pp. 23-27.

2. JT. Kloprogge, HD. Ruan, and RL. Frost: J. Mater. Sci., 2002, vol. 37 (6), pp. 1121-29.

3. E. Balomenos, D. Panias, and I. Paspaliaris: Miner. Process. Extr. Metall. Rev., 2011, vol. 32 (2), pp. 69-89.

4. J. Vind, A. Malfliet, C. Bonomi, P. Paiste, IE. Sajó, B. Blanpain, and D. Panias: Min. Eng., 2018, vol. 123, pp. 35-48.

5. J. Vind, A. Malfliet, B. Blanpain, P.E. Tsakiridis, A.H. Tkaczyk, V. Vassiliadou, and D. Panias: Minerals, 2018, vol. 8 (2), p. 77.

6. PE. Tsakiridis, S. Agatzini-Leonardou, and P. Oustadakis: $J$. Hazard. Mater., 2004, vol. 116 (1-2), pp. 103-10.

7. T. Hertel, B. Blanpain, and Y. Pontikes: J. Sustain. Metall., 2016, vol. 2 (4), pp. 394- 404.
8. B. Xakalashe and B. Friedrich: Proc. 2nd Int. Bauxite Residue and Valorisation and Best Practices Conf., 2018, pp. 233-40.

9. F. Kaußen and B. Friedrich: Chem. Ing. Tech., 2015, vol. 87 (11), pp. $1535-42$

10. CR. Borra, B. Blanpain, Y. Pontikes, K. Binnemans, and T. Van Gerven: J. Sustain. Metall., 2016, vol. 2 (1), pp. 28-37.

11. C. Cardenia, E. Balomenos, and D. Panias: J. Sustain. Metall., 2019, vol. 5 (1), pp. 9-19.

12. P.T. Yin, B.F. Buhle Xakalashe, D. Panias, and V. Vassiliadou: Proc. 35th Int. ICSOBA Conf., 2017, vol. 42, pp. 603-13.

13. J. Miller and A. Irgens: Light Metals, Springer, Cham, 1974, pp. $977-82$.

14. J. Safarian and L. Kolbeinsen: Sustainable Industrial Processing Summit, 2016, pp. 75-82.

15. J. Safarian and L. Kolbeinsen: Sustainable Industrial Processing Summit, 2016, pp. 1-8.

16. FI. Azof, L. Kolbeinsen, and J. Safarian: Metall. Mater. Trans. B, 2018, vol. 49B, pp. 2400-20.

17. W. Bo, S. Hui-lan, Z. Xue-zheng, and B. Shi-wen: Light Metals, Springer, Cham, 2011, pp. 241-44.

18. M. Vafeias, D. Marinos, D. Panias, J. Safarian, C. Van Der Eijk, I. Solhem, and P. Davris: Proc. 2nd Int. Bauxite Residue Valorisation and Best Practices Conf., 2018, pp. 111-17.

19. https://www.ntnu.edu/metpro/cri-metal-production.

20. https://www.ensureal.com/.

21. F.I. Azof, J. Safarian, and L. Kolbeinsen: Proc. 35th Int. ICSOBA Conf., 2017, vol. 42 (46), pp. 243-53.

22. FI. Azof, Y. Yang, D. Panias, L. Kolbeinsen, and J. Safarian: Hydrometallurgy, 2019, vol. 185, pp. 273-90.

23. A. Lazou, C. Van der Eijk, E. Balomenos, and J. Safarian: Proc. EMC Conf., 2019, vol. 1 (17), pp. 17-34.

24. A. Lazou, C. Van der Eijk, E. Balomenos, L. Kolbeinsen, and J. Safarian: Proc. 3rd Int. Bauxite Residue Valorisation and Best Practices Conf., 2020, pp. 77-83.

25. C.W. Bale, P. Chartrand, S.A. Degterov, G. Eriksson, K. Hack, R. Ben Mahfoud, and S. Petersen: Comput. Coupl. Phase Diagr. Thermochem., 2016, vol. 54, pp. 35-53.

26. AD. Pelton, G. Eriksson, and CW. Bale: Metall. Mater. Trans. A, 2017, vol. 48A, pp. 3113-29.

27. B. Hallstedl: J. Am. Ceram. Soc., 1990, vol. 73 (1), pp. 15-23.

28. LA. Dunyushkina, VA. Gorbunov, AA. Babkina, and NO. Esina: Ionics, 2003, vol. 9 (1-2), pp. 67-70.

29. FI. Azof: Pyrometallurgical and Hydrometallurgical Treatment of Calcium Aluminate-Containing Slags for Alumina Recovery, NTNU, Trondheim, Norway, 2020.

30. SJ. Kim, M. Kageyama, X. Gao, S. Ueda, and SY. Kitamura: ISIJ Int., 2019, vol. 59 (10), pp. 1752-55.

31. M. Hasegawa: Treatise on Process Metallurgy, 1st ed., Elsevier Ltd., Amsterdam, 2013, pp. 507-13.

32. J. Safarian, G. Tranell, L. Kolbeinsen, M. Tangstad, S. Gaal, and J. Kaczorowski: Metall. Mater. Trans. B, 2008, vol. 39B, pp. 702 12.

33. N. Tsuchiya, M. Tokuda, and M. Ohtani: Metall. Mater. Trans. B, 1976, vol. 7B, pp. 315-20.

34. J. Safarian, L. Kolbeinsen, M. Tangstad, and G. Tranell: Metall. Mater. Trans. B, 2009, vol. 40B, pp. 929-39.

35. Y. Morizane, B. Ozturk, and RJ. Fruehan: Metall. Mater. Trans. $B, 1999$, vol. 30B, pp. 29-43.

36. D. Shishin, T. Hidayat, U. Sultana, M. Shevchenko, and E. Jak: $J$. Sustain. Metall., 2020, vol. 6, pp. 68-77.

37. A.J. Andersson, Margareta T. Andersson, and P.G. Jönsson: Steel Res. Int., 2004, vol. 75 (5), pp. 294-301.

38. M.J. Mwase and J. Safarian: Proc. 38th Int. ICSOBA Conf., 2020, vol. 49, pp. 453-61.

39. K.T. Jacob and G. Rajitha: J. Phase Equilib. Diffus., 2012, vol. 33 (4), pp. 293-302.

40. JA. Imlach, LD. Glasser, and FP. Glasser: Cem. Concr. Res., 1971, vol. 1 (1), pp. 57-61.

41. RW. Nurse, JH. Welch, and AJ. Majumdar: Trans. Br. Ceram. Soc., 1965, vol. 64 (9), pp. 409-18.

42. DA. Jerebtsov and GG. Mikhailov: Ceram. Int., 2001, vol. 27 (1), pp. $25-28$.

43. N. Nityanand and HA. Fine: Metall. Mater. Trans. B, 1983, vol. 14B, pp. 685-92. 
44. JP. Eufinger, A. Schmidt, M. Lerch, and J. Janek: Phys. Chem. Chem. Phys., 2015, vol. 17 (10), pp. 6844-57.

45. H. Boysen, M. Lerch, A. Stys, and A. Senyshyn: Acta Crystallogr., Sect. B: Struct. Sci., 2007, vol. 63 (5), pp. 675-82.

46. J. Jeevaratnam, FP. Glasser, and LD. Glasser: J. Am. Ceram. Soc., 1964, vol. 47 (2), pp. 105-06.

47. BM. Mohamed and JH. Sharp: Thermochim. Acta, 2002, vol. 388 (1-2), pp. 105-14.
48. M. Ruszak, S. Witkowski, P. Pietrzyk, A. Kotarba, and Z. Sojka: Funct. Mater. Lett., 2011, vol. 4 (02), pp. 183-86.

49. Y.Y. Zhang, W. Lü, Y.H. Qi, and Z.S. Zou: Int. J. Miner., Metall. Mater., 2016, vol. 23 (8), pp. 881-90.

50. F.I. Azof and J. Safarian: Hydrometallurgy, 2020, vol. 195.

Publisher's Note Springer Nature remains neutral with regard to jurisdictional claims in published maps and institutional affiliations. 